\title{
Drill Hole Data for Coal Beds in the Powder River Basin, Montana and Wyoming
}

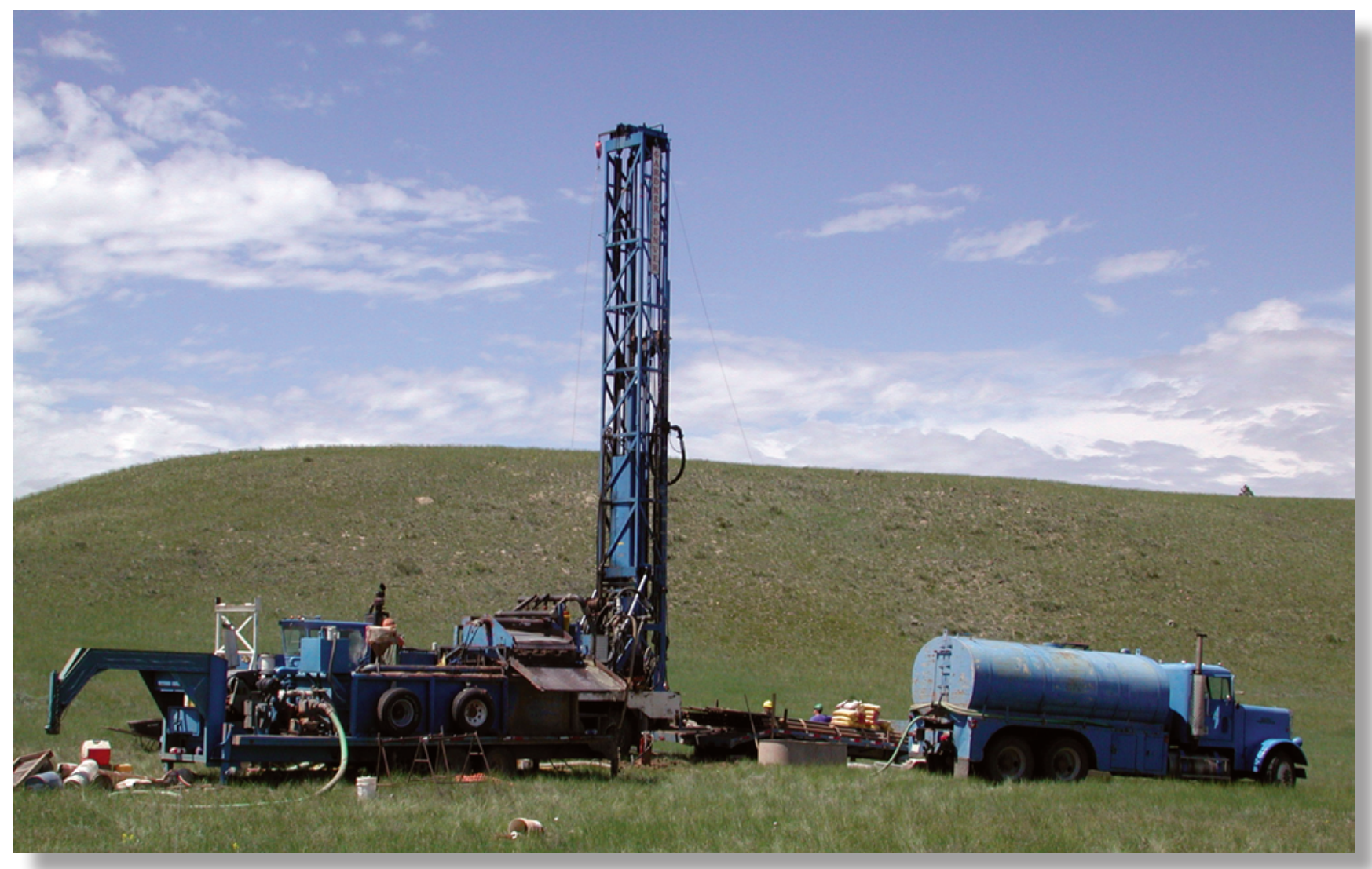

Data Series 713

U.S. Department of the Interior

U.S. Geological Survey 
Cover. Coalbed methane well in the Powder River Basin, Wyoming. Photograph by Margaret S. Ellis, U.S. Geological Survey, Denver, Colorado. 


\section{Drill Hole Data for Coal Beds in the Powder River Basin, Montana and Wyoming}

By Jon E. Haacke and David C. Scott

Data Series 713 


\section{U.S. Department of the Interior \\ KEN SALAZAR, Secretary}

\section{U.S. Geological Survey \\ Suzette M. Kimball, Acting Director}

U.S. Geological Survey, Reston, Virginia: 2013

For more information on the USGS - the Federal source for science about the Earth, its natural and living resources, natural hazards, and the environment, visit http://www.usgs.gov or call 1-888-ASK-USGS.

For an overview of USGS information products, including maps, imagery, and publications, visit http://www.usgs.gov/pubprod

To order this and other USGS information products, visit http://store.usgs.gov

Any use of trade, firm, or product names is for descriptive purposes only and does not imply endorsement by the U.S. Government.

Although this information product, for the most part, is in the public domain, it also may contain copyrighted materials as noted in the text. Permission to reproduce copyrighted items must be secured from the copyright owner.

Suggested citation:

Haacke, J.E., and Scott, D.C., 2013, Drill hole data for coal beds in the Powder River Basin, Montana and Wyoming: U.S. Geological Survey Data Series 713, 15 p. 


\section{Contents}

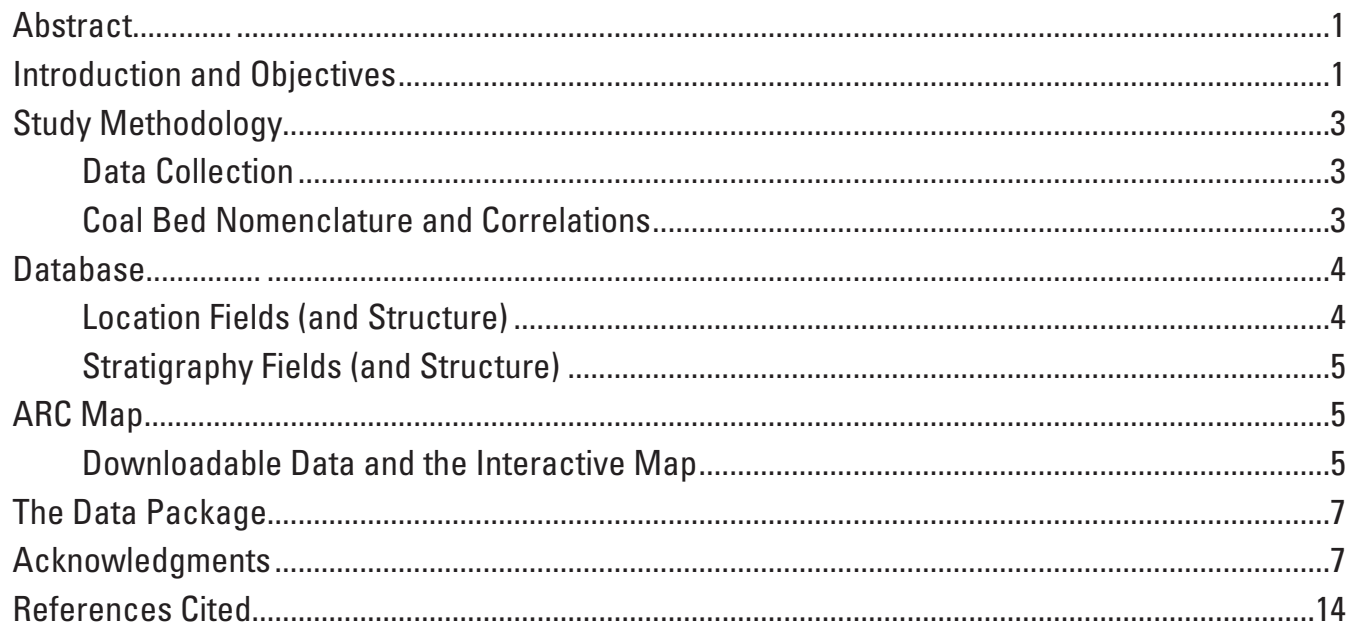

\section{Figure}

1. Map showing public domain drill hole locations for the Powder River Basin, Montana and Wyoming

\section{Tables}

1. List of the contents of the location table LITH_BY field showing the organization that made the lithology picks, and the number of drill holes entered.

2. List of the contents of the stratigraphy table FORMATION and BED fields showing the 47 coal beds, in stratigraphic order from youngest to oldest, in the Powder River Basin of Montana and Wyoming, and the number of drill holes encountering each bed

3. List of the contents of the location table TYPE field showing the drill hole types and the number of drill holes of each type.

4. Federal and State publications and online sources with original drill hole logs in the Powder River Basin. The publication number is contained in the location table DAT_SOURCE field. The Comment column describes the drill hole number series and type of logs contained.

5. List of the contents of the stratigraphy table PRIME_LITH and LITH_MOD fields and the number of occurrences of each combination. 


\section{Conversion Factors}

Inch/Pound to SI

\begin{tabular}{lcc}
\hline & Bultiply & To obtain \\
\hline & Length & \\
\hline foot $(\mathrm{ft})$ & 0.3048 & meter $(\mathrm{m})$ \\
\hline
\end{tabular}

Vertical coordinate information is referenced to the National Geodetic Vertical Datum of 1929 (NAVD 29).

Horizontal coordinate information is referenced to the North American Datum of 1927 (NAD27).

Elevation, as used in this report, refers to distance above the vertical datum. 


\title{
Drill Hole Data for Coal Beds in the Powder River Basin, Montana and Wyoming
}

\author{
By Jon E. Haacke and David C. Scott
}

\section{Abstract}

This report by the U.S. Geological Survey (USGS) of the Powder River Basin (PRB) of Montana and Wyoming is part of the U.S. Coal Resources and Reserves Assessment Project. Essential to that project was the creation of a comprehensive drill hole database that was used for coal bed correlation and for coal resource and reserve assessments in the PRB. This drill hole database was assembled using data from the USGS National Coal Resources Data System, several other Federal and State agencies, and selected mining companies. Additionally, USGS personnel manually entered lithologic picks into the database from geophysical logs of coalbed methane, oil, and gas wells. Of the 29,928 drill holes processed, records of 21,393 are in the public domain and are included in this report. The database contains location information, lithology, and coal bed names for each drill hole.

\section{Introduction and Objectives}

The PRB was previously assessed for coal resources and reserves by the USGS and other Federal and State agencies. These assessments generally involved studies that covered only limited geographic areas and (or) limited depths. The current U.S. Coal Resources and Reserves Assessment Project expanded the scope of past studies to include the entire PRB, all coal beds, and at all depths. For this purpose, the PRB was divided into four assessment areas to permit more timely publication of assessment results. These assessment areas (fig. 1) are (1) Gillette coal field (Luppens and others, 2008), (2) Northern Wyoming PRB (Scott and others, 2010),
(3) Southwestern PRB (Osmonson and others, 2011), and

(4) Montana PRB (Haacke and others, 2012).

As a foundation for the PRB assessment, the largest possible drill hole database was assembled. The core of the digital database came from the U.S. Geological Survey National Coal Resources Data System (NCRDS, http:// energy.er.usgs.gov/products/databases/CoalQual/index.htm). Additional digital data were supplied by the Wyoming State Geological Survey (WSGS, http://www.wsgs.uwyo.edu/), the Montana Bureau of Mines and Geology (MBMG, http://www. mbmg.mtech.edu/), the Bureau of Land Management (BLM, http://www.blm.gov/wo/st/en.html), and a commercial database created by Goolsby, Finley, and Associates, LLC (Goolsby and others, 2001) that was released to public domain. Confidential drill hole data were loaned to the USGS by several mining companies operating in the PRB. A substantial amount of new data is now available from the recent development of coalbed methane (CBM) in Wyoming and Montana. Geophysical logs of an additional 13,358 CBM, oil, and gas wells were examined and the lithology picks entered in the database using the StratiFact ${ }^{\mathbb{B}}$ (GRG Corporation, 1998) drill hole database and graphics program (table 1).

The correlation of all coal beds was determined using the StratiFact program, with some 250,000 cross-sections viewed in order to place 47 coal beds into a single stratigraphic system. The interpretations from this greatly expanded database provided a more accurate view of the coal resources and reserves in the PRB. The resulting correlated database contained 29,928 drill holes, of which 21,393 are public domain (fig. 1). Each of the four assessment area reports, listed above, using the correlated drill hole dataset, contains discussions on geology, coal resources, and reserves tonnages. The purpose of this report is to make the drill hole data available to the public.

Table 1. List of the contents of the location table LITH_BY field showing the organization that made the lithology picks, and the number of drill holes entered.

\begin{tabular}{cll}
\hline Number of holes & Field contents & \multicolumn{1}{c}{ Full name } \\
\hline 697 & GFA & Goolsby, Finley, and Associates, LLC \\
1,034 & MBMG & The Montana Bureau of Mines and Geology \\
697 & USBLM & The Bureau of Land Management \\
16,732 & USGS & The U.S. Geological Survey \\
2,233 & WSGS & The Wyoming State Geological Survey \\
\hline
\end{tabular}




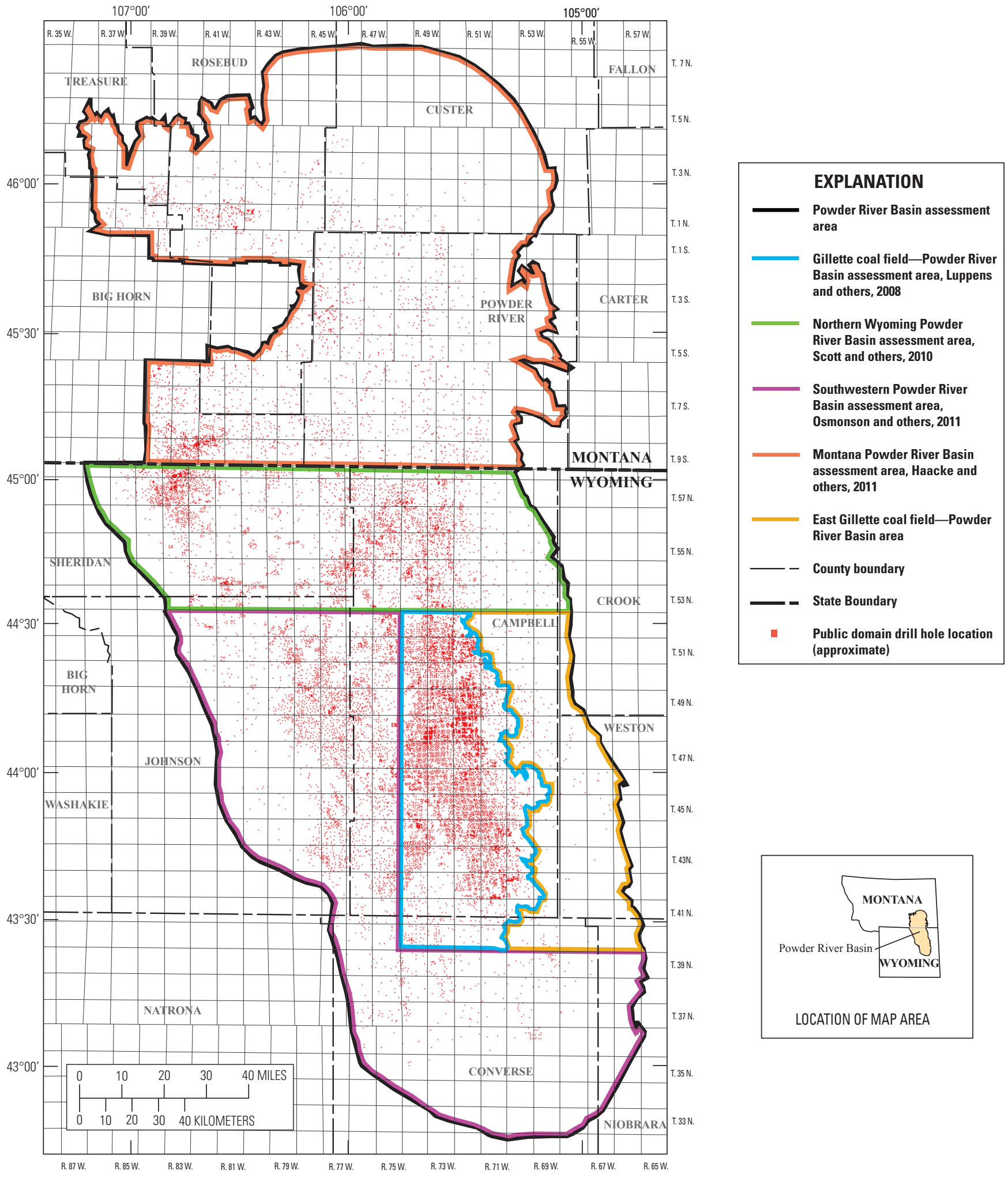

Figure 1. Map showing public domain drill hole locations for the Powder River Basin, Montana and Wyoming. Locations are approximate. 


\section{Study Methodology}

Two steps were used in producing the completed drill hole database (1) data collection and (2) coal bed correlation. The assessment process is discussed in detail in the four individual assessment reports.

\section{Data Collection}

The first phase in data collection began with a search of the USGS NCRDS database that contains coal drill hole and measured section data for the United States collected by the USGS and various State agencies. The NCRDS data that came from WSGS and MBMG were later augmented by additional digital data supplied by those State agencies. Coal companies having activity in the PRB were approached with requests for use of their data in the assessments and several supplied digital data upon conditions of anonymity and data confidentiality.

The next phase involved entering data from CBM, oil, and gas wells. In the mid-1990s, CBM drilling in the Wyoming portion of the PRB increased rapidly, and by 1999 thousands of CBM wells were being drilled. By the time that the PRB assessment project began in 2004 the large number of new publically available CBM wells as well as thousands of older oil and gas wells allowed a more comprehensive evaluation of geology and coal resources than had been possible in previous studies. TIFF images of drill hole geophysical logs, selected for data entry into StratiFact, were downloaded from the Wyoming Oil and Gas Conservation Commission (WOGCC) web site as were drill hole coordinates for all Wyoming wells.

In Montana, CBM, oil, and gas drilling is limited. CBM development has been restricted to an area south and east of the town of Decker (which is about 75 miles southeast of Billings). Additionally, oil and gas exploration and development in the Montana PRB has been much less extensive than in Wyoming. The result is a significant lack of publicly available drill hole data in Montana as compared with Wyoming. Geophysical logs for Montana were purchased from MJ Systems (2009) and converted to TIFF format. Drill hole coordinates for all Montana wells were downloaded from the Montana Board of Oil and Gas (Montana Board of Oil and Gas, 2006).

The drill hole coordinates and elevations were derived from a variety of sources, accuracy of most of these data is unknown. A concentrated effort was made to check drill hole locations but, lacking access to much of the original data, locations of many drill hole could not be verified. The latitudes, longitudes and elevations of CBM, oil, and gas wells came from the respective oil and gas commissions of Montana and Wyoming, having been supplied by the operators of the wells. Both state commissions assume the coordinates and elevations to be in NAD 27 datum but it is not required. In addition, the state commissions only require that the well be in the permitted quarter-quarter of a section, so the coordinates may only be approximate. Overall, drill holes in this database are believed to have sufficiently accurate coordinates and elevations for regional coal correlations.

Other factors add to the variability in data consistency for entries in this database because (1) geophysical logs differ widely in type, quality, and resolution; (2) in a majority of CBM wells, only gamma ray logs were run and many of those were logged through drill pipe or casing; and (3) hundreds of wells were logged only to the top of the target coal. Oil and gas wells were logged primarily for detail in deep formations, and typically the upper (coal-bearing) intervals were either not logged or only gamma logged through the surface casing.

Lithology picks from geophysical logs were entered into the StratiFact program. The primary focus of the PRB assessment was to determine coal resources and reserves rather than to conduct a comprehensive geological study; therefore, no attempt was made to interpret non-coal lithologies and in cases where the lithology was not already described in detail, lithologies were coded as coal or rock. Partings within coal beds and interburden between coal beds were also coded as rock. An interval for which there was no geophysical logging, such as the shallower part of an oil or well or a CBM well that was not logged to the bottom of the well, was entered as "No Log." However, if the methane-producing interval of the CBM well was available from production records, that interval was entered as "Coal, CBM Perf." For some data supplied to the USGS, only coal picks were recorded and the non-reported intervals were entered as "Not Reported." In some cases, those non-reported intervals possibly had coals that were not considered significant. Therefore the "No Log" and "Not Reported" intervals should be considered as null information rather than as not having any coal for correlation and modeling purposes. In all, lithologic data from 9,565 CBM wells and 3,091 oil and gas wells in Wyoming, and 290 CBM wells and 412 oil and gas wells in Montana were entered in the database.

\section{Coal Bed Correlations and Nomenclature}

The second step in producing the database was the correlation of coal beds. Historically, correlation of individually named coal beds and coal zones across the entire PRB has been difficult, because the beds commonly split, merge, and pinch out (Flores and others, 1999). Also, distances between individual drill holes were often widely spaced, increasing the uncertainty of coal bed correlations from one drill hole to the next. However, with this greatly expanded database, the distance between drill holes was reduced resulting in a higher density of subsurface data and increased correlation reliability.

Many different names for individual coal beds and coal zones in the PRB have been used during the past 30 years. A report by Kent and others (1980), who described the northern part of the Gillette coal field that falls within the Spotted Horse coal field of Olive (1957), established a coal bed nomenclature system that has become the standard for much of the PRB in Wyoming. Kent and others (1980) retained certain existing coal bed nomenclature and revised 
other nomenclature by introducing new coal bed names. Molnia and Pierce (1992) also described coal bed stratigraphy in the central PRB in Wyoming and Montana; their nomenclature followed the usage of Culbertson and others (1979), Law and others (1979), Kent and others (1980), and Culbertson and Saperstone (1987). Flores and others (1999) defined a coal zone in the PRB known as the Wyodak-Anderson, which includes many named coal beds in the upper part of the Tongue River Member of the Fort Union Formation. Five previously published regional cross sections were particularly instrumental in setting the framework for coal bed correlations in the PRB (1) McLellan and others (1990), (2) Pierce and others (1990), (3) Hardie (1991), (4) McLellan (1991), and (5) Molnia and Pierce (1992). Coal bed names used in this and previous reports are discussed in the four individual assessment reports mentioned earlier. The formation and bed names used in this report and the number of holes that encountered each coal bed are given in table 2 .

The graphical interface of the StratiFact database was a critical tool for managing the interpretation of the large volume of information. On-screen cross sections were selected, edited, and correlated. Both linear and circular cross sections were constructed to correlate coal beds across the PRB assessment area. Circular cross sections that verify closure were especially valuable when coal beds either split or thinned adjacent to sand channels. In this process, the beginning and ending drill holes of the cross section are the same, assuring correlation accuracy.

Guidelines were established regarding how to handle situations in which two named beds merged into a single bed. The general guideline used in these cases was that two named beds were considered to have merged into a single named bed when an intervening parting was less than $2.0 \mathrm{ft}$ thick. The following exceptions were made for modeling purposes:

- In individual holes, coal beds split by partings as much as $5.0 \mathrm{ft}$ thick were considered to be merged if surrounding holes indicate the beds had merged into a single bed.

- In individual holes, coal beds with no partings or partings less than $2.0 \mathrm{ft}$ thick were considered to be split into two beds if surrounding holes showed the coal has split into two beds.

- The upper bed's name was used for the merged-bed name, except in the case of a rider bed that merged into the main bed; for example, where the Anderson bed merged with the Upper Anderson Rider bed, the resulting bed was considered the Anderson bed.

\section{Database}

The database consists of two tables, the location table and the stratigraphy table. The data in the two tables are linked by unique id numbers assigned to each drill hole. Each table is supplied in two formats, containing identical data. The quote and comma delimited format files have a "CSV" extension; the dbase format files have a "DBF" extension.

The following section lists the fields in the database tables. Each field name is described as a Character, Integer, or Numeric field along with the size of the field. There is also a brief description of the purpose of each field and for some fields the specific contents of each field.

\section{Location Fields (and Structure)}

UNIQUE_ID (Integer)

Unique number assigned to each drill hole to relate data in the location table to those in the stratigraphy table. Numbered from 1 to the total number of drill holes in the database.

HOLE_ID (Character)

The drill hole identifier assigned by the company or agency who drilled the well, except for CBM, oil, and gas wells where the standard API number is used

LAT_NAD27 (Numeric, 5 decimals)

The Latitude coordinate, expressed in decimal degrees, in NAD 27 datum

LONG_NAD27 (Numeric, 5 decimals)

The Longitude coordinate, expressed in decimal degrees, in NAD 27 datum.

UTME_NAD27 (Numeric, 2 decimals) Universal Transverse Mercator coordinates, expressed in meters, zone 13, in NAD 27 datum. Values were converted from the Latitude and Longitude coordinates using the Army Corps of Engineers Corpscon 6 software.

UTMN_NAD27 (Numeric, 2 decimals) Universal Transverse Mercator coordinates, expressed in meters, zone 13, in NAD 27 datum. Values were converted from the Latitude and Longitude coordinates using the Army Corps of Engineers Corpscon 6 software.

ELEVATION (Numeric, 2 decimals)

Surface elevation of all drill holes, except for oil wells where the elevation is taken at the kelly bushing.

DH_DEPTH (Numeric, 2 decimals)

The drilled depth of the drill hole. 
TOWNSHIP (Character)

Township within the $6^{\text {th }}$ Principal Meridian.

RANGE (Character)

Range within the $6^{\text {th }}$ Principal Meridian.

SECTION (Numeric, 2 decimals)

The Section within a township and a range.

QTR_QTR (Character)

The Quarter, Quarter within a Section.

STATE (Character)

Contents are either Montana or Wyoming. There are 2,925

holes in Montana and 18,469 holes in Wyoming.

COUNTY (Character)

Contains the county name.

TYPE (Character)

Type of drill hole (table 3).

DAT_SOURCE (Character)

Data source with original drill hole information from which lithology picks were made. Much of the original drill hole data is publically available from publications and online sources. A detailed list of the sources with comments is in table 4.

\section{LITH_BY (Character)}

Name of the agency, organization, or company that made the lithology picks (table 1). Where available, the field also contains the name of the individual who made the picks.

\section{COMPANY (Character)}

For CBM, oil, and gas wells, this field contains the name of the company for which the well was drilled. For holes drilled for coal, this field either contains the name of the mining company or the government agency. There are 1,014 different entries in this field.

WELL_NAME (Character)

Contains the common well name for CBM, oil, and gas wells.

QUAD_MAP (Character)

Contains the name of the USGS 7.5 minute quadrangle map.

\section{Stratigraphy Fields (and Structure)}

\section{UNIQUE ID (Integer)}

This is the unique number assigned to each drill hole to relate data in the stratigraphy table to the location table. Numbered from 1 to the total number of drill holes in the database.
HOLE ID (Character)

The drill hole identifier assigned by the company or agency who drilled the well, except for CBM, oil, and gas wells where the standard API number is used

TOP_DEPTH (Numeric, 2 decimals)

This is the depth, in feet, from the surface to the top of each lithologic unit.

BOT_DEPTH (Numeric, 2 decimals)

This is the depth, in feet, from the surface to the bottom of each lithologic unit.

PRIME_LITH and LITH_MOD (Character)

These two fields contain the primary lithology and lithology modifier for every stratigraphic record (table 5).

FORMATION (Character, 16) and BED (Character)

These two fields contain the correlated formation and coal bed names (table 2).

\section{ARC Map}

Supplemental to the database are GIS data created using Esri ArcGIS 9.3.1 (Esri, 2000) that can be used to show the drill hole database in map view along with other pertinent data layers. These layers include surface geology, coal assessment study area boundaries, townships and ranges, generalized surface ownership, topography, and various cultural features that are also included in basemap GIS services provided by Esri, Inc. (Esri, 2010).

\section{Downloadable Data and the Interactive Map}

The GIS is available for interactive analysis as a map document (both MXD and PMF formats) that can be downloaded from the USGS website at http://pubs.usgs.gov/ds/713/. Because of the ability to toggle layers on and off and analyze attributes, data analysis can be achieved effectively with the interactive map. The publishing process uses the ArcMap document (MXD) and creates a special file called a published map file (PMF). ArcGIS Publisher (Esri, 2008a, http://www.esri. $\mathrm{com} /$ software/arcgis/extensions/publisher/index.html) is the extension used to create the PMF from the MXD and packages the required data with the PMF file for easy distribution. PMFs can be viewed or printed using any ArcGIS (Esri, 2000, http:// www.esri.com/software/arcgis/) desktop product, including ArcMap and the no-cost ArcReader (Esri, 2008b, http://www. esri.com/software/arcgis/arcreader/download.html) application. Users can download and install the ArcReader software 
Table 2. List of the contents of the stratigraphy table FORMATION and BED fields showing the 47 coal beds, in stratigraphic order from youngest to oldest, in the Powder River Basin of Montana and Wyoming, and the number of drill holes encountering each bed.

\begin{tabular}{|c|c|c|}
\hline $\begin{array}{c}\text { Number of } \\
\text { holes }\end{array}$ & Formation & Bed \\
\hline 186 & Wasatch & Upper Healy \\
\hline 658 & Wasatch & Healy/Lower Ulm \\
\hline 785 & Wasatch & Murray \\
\hline 591 & Wasatch & Ucross \\
\hline 1,989 & Wasatch & Upper Felix \\
\hline 4,444 & Wasatch & Felix \\
\hline 4,109 & Wasatch & Lower Felix \\
\hline 5,710 & Fort Union & Upper Roland Rider \\
\hline 1,619 & Fort Union & Lower Roland Rider \\
\hline 9,987 & Fort Union & Roland (Baker) \\
\hline 953 & Fort Union & Roland (Taff) \\
\hline 326 & Fort Union & Upper Smith \\
\hline 9,334 & Fort Union & Smith \\
\hline 343 & Fort Union & Upper Anderson Rider \\
\hline 480 & Fort Union & Lower Anderson Rider \\
\hline 11,775 & Fort Union & Anderson \\
\hline 883 & Fort Union & Lower Anderson \\
\hline 672 & Fort Union & Dietz 1 \\
\hline 930 & Fort Union & Dietz 2 \\
\hline 4,816 & Fort Union & Dietz 3 \\
\hline 624 & Fort Union & Dietz 4 \\
\hline 726 & Fort Union & Upper Canyon/Cox \\
\hline 9,354 & Fort Union & Canyon \\
\hline 4,374 & Fort Union & Lower Canyon \\
\hline 145 & Fort Union & Upper Ferry \\
\hline 744 & Fort Union & Ferry \\
\hline 4,460 & Fort Union & Werner/Cook \\
\hline 328 & Fort Union & Upper Otter \\
\hline 3,642 & Fort Union & Otter \\
\hline 3,412 & Fort Union & Gates/Wall \\
\hline 1,368 & Fort Union & Pawnee \\
\hline 110 & Fort Union & Brewster-Arnold \\
\hline 1,052 & Fort Union & Odell \\
\hline 247 & Fort Union & Cache \\
\hline 24 & Fort Union & A Zone \\
\hline 44 & Fort Union & Upper Rosebud/S1 \\
\hline 2,206 & Fort Union & Rosebud/Knobloch \\
\hline 86 & Fort Union & Calvert \\
\hline 2,499 & Fort Union & Mckay/Nance \\
\hline 63 & Fort Union & Lower Mckay/S2 \\
\hline 2,752 & Fort Union & Flowers-Goodale/Danner \\
\hline 1 & Fort Union & Upper Witham \\
\hline 1,491 & Fort Union & Robinson/Witham \\
\hline 1,768 & Fort Union & Roberts/Terret \\
\hline 50 & Fort Union & Burley \\
\hline 91 & Fort Union & Upper Stag \\
\hline 8 & Fort Union & Lower Stag \\
\hline
\end{tabular}


from Esri. To access the MXD, users must have Arc GIS 9.3.1 or later software (Esri, 2000, http://www.esri.com/software/ arcgis/eval-help/arcgis-931.html).

The ArcMap project is a compilation of both published and unpublished coal geology data. For the published data, the accompanying metadata have been retained as published. For the ArcGIS.com web services (formerly ArcGIS Online; Esri, 2010, http://www.esri.com/software/arcgis/arcgisonline/index. html), data descriptions, sources, and credits are stored as layer properties.

\section{The Data Package}

The report, whether downloaded from a USGS web site or from the CD consists of the text of this report (the pamphlet), the drill hole database, and the GIS data. The Data folder contains the drill hole database in CSV and DBF formats. The GIS folder contains the PRB drill holes.MXD and PRB_drill_holes.PMF files. All GIS data are stored in a geodatabase using the GCS_North_American_1983 coordinate system and reside in the 'PRB_drill_holes.gdb' folder within the GIS folder.

\section{Acknowledgments}

We would like to thank the staff of the Wyoming State Geological Survey, and Jay Gunderson of the Montana Bureau of Mines and Geology for supplying drill-hole data. The outstanding efforts of Laura R.H. Biewick and Lee M. Osmonson (U.S. Geological Survey) in creating the GIS map were extremely appreciated. Ronald H. Affolter, Scott A. Kinney, William R. Keefer, and Margaret S. Ellis, all of the U.S. Geological Survey, provided technical reviews of the manuscript which greatly improved this report.

Table 3. List of the contents of the location table TYPE field showing the drill hole types and the number of drill holes of each type.

\begin{tabular}{ccl}
\hline Number of holes & Field contents & \multicolumn{1}{c}{ Comment } \\
\hline 12,553 & CBM & Coalbed methane well \\
3,503 & Coal test & Drilled for exploration and/or development of coal \\
5,003 & Oil \& gas & Oil and gas well \\
334 & Water well & Originally drilled as a water well \\
\hline
\end{tabular}


Table 4. Federal and State publications and online sources with original drill hole logs in the Powder River Basin. The publication number is contained in the location table DAT_SOURCE field. The Comment column describes the drill hole number series and type of logs contained.

\begin{tabular}{|c|c|}
\hline Source Publication & Comments \\
\hline $\begin{array}{l}\text { Babcock, R.N. and Hobbs, R.G., 1979, Geophysical logging of water } \\
\text { wells for coal occurrences in northern Campbell County and eastern } \\
\text { Sheridan County, Wyoming: U.S. Geological Survey Open-File Report } \\
79-1213,12 \text { p. }\end{array}$ & $\begin{array}{l}\text { Table listing of coal picks for holes numbered } 76-\mathrm{BCR}-1 \text { through } \\
76-\mathrm{BCR}-11,77-\mathrm{BCR}-1 \text { through } 77-\mathrm{BCR}-63 \text {, and } 78-\mathrm{BCR}-1 \\
\text { through } 78-\mathrm{BCR}-5 \text {. The published database contains } 1 \text { drill hole } \\
\text { from this source publication. }\end{array}$ \\
\hline $\begin{array}{l}\text { Cathcart, J.D., 1984, Bibliography of U.S. Geological Survey reports } \\
\text { on coal drilling and geophysical logging projects, and related re- } \\
\text { ports on geologic uses, Powder River Basin, Montana and Wyoming, } \\
\text { 1973-1983: U.S. Geological Survey Open-File Report 84-518, } 16 \text { p. }\end{array}$ & $\begin{array}{l}\text { This publication lists most of the U.S. Geological Survey publica- } \\
\text { tions listed in this bibliography and well as many other publica- } \\
\text { tions. }\end{array}$ \\
\hline $\begin{array}{l}\text { Cathcart, J.D. and Roberts, S.B., 1982, Preliminary report of coal ex- } \\
\text { ploration drilling in the Broadus Area, Powder River County, Montana, } \\
\text { during 1980: U.S. Geological Survey Open-File Report 82-828, } 113 \text { p. }\end{array}$ & $\begin{array}{l}\text { Lithology logs and geophysical logs for holes numbered } 80-\mathrm{MB}- \\
\text { A1 through } 80-\mathrm{MB}-\mathrm{E} 9 \text {. The published database contains } 18 \text { drill } \\
\text { holes from this source publication. }\end{array}$ \\
\hline $\begin{array}{l}\text { Cathcart, J.D., Babcock, R.N. and Hobbs, R.G., 1983, Geophysical } \\
\text { logs of water wells logged for coal occurrences in northern Campbell } \\
\text { and eastern Sheridan Counties, Wyoming: U.S. Geological Survey } \\
\text { Open-File Report 83-411, } 119 \text { p. }\end{array}$ & $\begin{array}{l}\text { Geophysical logs for holes numbered 76-BCR-1 through } 76- \\
\text { BCR-11, 77-BCR-1 through 77-BCR-63, and 78-BCR-1 } \\
\text { through 78-BCR-5. The published database contains } 1 \text { drill hole } \\
\text { from this source publication. }\end{array}$ \\
\hline $\begin{array}{l}\text { Correia, G.A., 1980, Preliminary results of } 1978 \text { coal assessment drill- } \\
\text { ing in northern and western Recluse Geologic Analysis Area, northern } \\
\text { Campbell County and eastern Sheridan County, Wyoming: U.S. Geo- } \\
\text { logical Survey Open-File Report } 80-80,70 \text { p. }\end{array}$ & $\begin{array}{l}\text { Geophysical logs for holes numbered } 78-1 \text { through } 78-31 . \text { The } \\
\text { published database contains } 15 \text { drill holes from this source publi- } \\
\text { cation. }\end{array}$ \\
\hline $\begin{array}{l}\text { Culbertson, W.C., 1981, Coal exploratory holes drilled in } 1980 \text { in } \\
\text { the Birney } 1 \text { degree } \times 2 \text { degrees Quadrangle, Powder River and Big } \\
\text { Horn Counties, Montana: U.S. Geological Survey Open-File Report } \\
81-1329,54 \text { p. }\end{array}$ & $\begin{array}{l}\text { Lithology logs and geophysical logs for holes numbered OTTER } \\
1 \text { through OTTER } 10 . \text { The published database contains } 9 \text { drill } \\
\text { holes from this source publication. }\end{array}$ \\
\hline $\begin{array}{l}\text { Culbertson, W.C., Gaffke, T.M., and Correia, G.A., 1980, Coal explor- } \\
\text { atory holes drilled in 1978-79 in the Birney } 1 \text { degree by .5 degrees } \\
\text { Quadrangle, Big Horn and Rosebud Counties, Montana, for coal beds } \\
\text { in the Tongue River Member of the Paleocene Fort Union Formation: } \\
\text { U.S. Geological Survey Open-File Report } 80-55,68 \text { p. }\end{array}$ & $\begin{array}{l}\text { Lithology logs and geophysical logs for holes numbered BIRNEY } \\
1 \text { through BIRNEY } 10 \text {. The published database contains } 13 \text { drill } \\
\text { holes from this source publication. }\end{array}$ \\
\hline $\begin{array}{l}\text { Hansen, W.B. and Culbertson, W.C., 1985, Correlated lithologic logs } \\
\text { and analyses of } 1982 \text { coal drilling in Big Horn, Prairie, Rosebud, and } \\
\text { Treasure Counties, Montana: U.S. Geological Survey Open-File Report } \\
85-738,125 \text { p. }\end{array}$ & $\begin{array}{l}\text { Lithology logs for holes numbered B-82-1 thru B-82-28, } \\
\text { PDC-13 and PDC-14, R-82-1 through R-82-20, CC-13-82, } \\
\text { CC-14-2, CC-19-82, and CC-20-82. The published database } \\
\text { contains } 43 \text { drill holes from this source publication. }\end{array}$ \\
\hline $\begin{array}{l}\text { Hobbs, R.G., 1980, } 1976 \text { coal exploratory drilling: core description, } \\
\text { and coal analyses, Recluse Geologic Analysis Area, northern Campbell } \\
\text { County, Wyoming: U.S. Geological Survey Open-File Report 80-1160, } \\
53 \text { p. }\end{array}$ & $\begin{array}{l}\text { Lithology logs and coal quality for holes numbered } 76-103 \text {, } \\
76-105 \text {, and } 76-108 . \text { The published database contains } 2 \text { drill } \\
\text { holes from this source publication. }\end{array}$ \\
\hline $\begin{array}{l}\text { Hobbs, R.G., 1980, Analyses of coal and selected rock samples from } \\
\text { the USGS } 1975 \text { drilling, Recluse Geologic Analysis area, northern } \\
\text { Campbell County, Wyoming: U.S. Geological Survey Open-File Re- } \\
\text { port 80-1161, } 78 \text { p. }\end{array}$ & $\begin{array}{l}\text { Coal quality for holes numbered RM-1 through RM-7. See } \\
\text { Open-File Report } 77-717 \text { for lithology logs. The published data- } \\
\text { base contains no drill holes from this source publication. }\end{array}$ \\
\hline $\begin{array}{l}\text { Hobbs, R.G., 1982, Coal exploratory drilling 1980, Recluse and } \\
\text { Sheridan .5 degree by } 1 \text { degree Quadrangles, Campbell, Johnson, and } \\
\text { Sheridan Counties, Wyoming: U.S. Geological Survey Open-File } \\
\text { Report } 82-799,158 \text { p. }\end{array}$ & $\begin{array}{l}\text { Lithology logs and geophysical logs for holes numbered } 80-\mathrm{AU} 1 \\
\text { through } 80 \text {-AU26. The published database contains } 18 \text { drill holes } \\
\text { from this source publication. }\end{array}$ \\
\hline
\end{tabular}


Table 4. Federal and State publications and online sources with original drill hole logs in the Powder River Basin. The publication number is contained in the location table DAT_SOURCE field. The Comment column describes the drill hole number series and type of logs contained.-Continued

\begin{tabular}{|c|c|}
\hline Source Publication & Comments \\
\hline $\begin{array}{l}\text { Hobbs, R.G., Malotte, D.C., Sanchez, J.D., and Windolph, J.F., Jr., } \\
\text { 1977, Core description logs, } 1975 \text { USGS drilling, Recluse area, north- } \\
\text { ern Campbell County, Wyoming: U.S. Geological Survey Open-File } \\
\text { Report 77-717, } 46 \text { p. }\end{array}$ & $\begin{array}{l}\text { Lithology logs for holes numbered RM- } 1 \text { through RM- } 7 \text {. The } \\
\text { associated coal quality data are in Open-File Report } 80-1161 \text {. The } \\
\text { published database contains } 4 \text { drill holes from this source publica- } \\
\text { tion. }\end{array}$ \\
\hline $\begin{array}{l}\text { Kepferle, R.C., 1954, Selected deposits of strippable coal in central } \\
\text { Rosebud County, Montana: U.S. Geological Survey Bulletin 995-I, } 49 \\
\text { p, } 5 \text { pls. }\end{array}$ & $\begin{array}{l}\text { Contains numerous measured sections. The published database } \\
\text { contains } 1 \text { drill hole from this source publication. }\end{array}$ \\
\hline $\begin{array}{l}\text { Kirschbaum, M. A., Correia, G. A., and McPhillips, M., 1982, Coal } \\
\text { exploratory drilling during } 1979 \text { in western Powder River County, } \\
\text { Montana: U.S. Geological Survey Open-File Report 82-748, } 141 \text { p. }\end{array}$ & $\begin{array}{l}\text { Lithology logs and geophysical logs for holes numbered MB-1C } \\
\text { through MB-36. The published database contains } 36 \text { drill holes } \\
\text { from this source publication. }\end{array}$ \\
\hline $\begin{array}{l}\text { Kistner, F.B., 1977, Preliminary report on five coal drill holes in } \\
\text { Converse County, Wyoming: U.S. Geological Survey Open-File Report } \\
77-774,25 \text { p. }\end{array}$ & $\begin{array}{l}\text { Lithology logs and geophysical logs for holes numbered GS-7601 } \\
\text { through GS-7605. The published database contains } 2 \text { drill holes } \\
\text { from this source publication. }\end{array}$ \\
\hline $\begin{array}{l}\text { Kistner, F.B., Holloman, G.A., and Coppock, D.G., 1979, Lithologic } \\
\text { and geophysical logs and coal analyses from test holes drilled during } \\
1977 \text { in Converse and Campbell Counties, Wyoming: U.S. Geological } \\
\text { Survey Open-File Report 79-1173, } 88 \text { p. }\end{array}$ & $\begin{array}{l}\text { Geophysical logs for holes numbered CD-77001 through } \\
\text { CD-77028. The published database contains } 22 \text { drill holes from } \\
\text { this source publication. }\end{array}$ \\
\hline $\begin{array}{l}\text { Kistner, F.B., Donatich, A.J., and Holloman, G.A., 1980, Geophysi- } \\
\text { cal and lithologic logs and coal analyses from test holes drilled during } \\
1978 \text { in Campbell and Converse Counties, Wyoming: U.S. Geological } \\
\text { Survey Open-File Report 80-851, } 183 \text { p. }\end{array}$ & $\begin{array}{l}\text { Lithology logs and geophysical logs for holes numbered CD- } \\
78001 \text { through CD-78081. The published database contains } 47 \\
\text { drill holes from this source publication. }\end{array}$ \\
\hline $\begin{array}{l}\text { Lonnie, T.P., Corley, H.E., and Noah, R.J., 1980, Geophysical and } \\
\text { lithologic logs from coal test holes drilled during } 1979 \text { in Converse } \\
\text { and Campbell Counties, Wyoming: U.S. Geological Survey Open-File } \\
\text { Report } 80-1041,102 \text { p. }\end{array}$ & $\begin{array}{l}\text { Geophysical logs for holes numbered CD-79001 through } \\
\text { CD-79056. The published database contains } 56 \text { drill holes from } \\
\text { this source publication. }\end{array}$ \\
\hline $\begin{array}{l}\text { Matson, R.E., 1971, Strippable coal in the Moorhead Coal Field, Mon- } \\
\text { tana: Montana Bureau of Mines and Geology Bulletin 83, } 18 \text { p., } 3 \text { pls. }\end{array}$ & $\begin{array}{l}\text { Lithology logs and location maps for drill holes numbered SM-1 } \\
\text { through SM-19, SH-61 through SH-64, and SH-7041 through } \\
\text { SH-7043. The published database contains } 18 \text { drill holes from } \\
\text { this source publication. }\end{array}$ \\
\hline $\begin{array}{l}\text { Matson, R.E. and Blumer, J.E., 1973, Quality and reserves of strippable } \\
\text { coal, selected deposits, southeastern Montana: Montana Bureau of } \\
\text { Mines and Geology Bulletin 91, } 135 \text { p, } 34 \text { pls., } 4 \text { figures, } 91 \text { tables. }\end{array}$ & $\begin{array}{l}\text { Lithology logs and location maps for drill holes numbered } \mathrm{SH}-1 \\
\text { through } \mathrm{SH}-121, \mathrm{SH}-701 \text { through } \mathrm{SH}-70102 \text {, and } \mathrm{SH}-711 \\
\text { through } \mathrm{SH}-7195 . \text { The published database contains } 443 \text { drill holes } \\
\text { from this source publication. }\end{array}$ \\
\hline $\begin{array}{l}\text { Pierce, W.G., 1936, Contributions to economic geology (short papers } \\
\text { and preliminary reports), 1934-36. The Rosebud coal field, Rose- } \\
\text { bud and Custer Counties, Montana: U.S. Geological Survey Bulletin } \\
847-B, 78 \text { pages, } 17 \text { pls. }\end{array}$ & $\begin{array}{l}\text { Contains numerous measured sections. The published database } \\
\text { contains } 3 \text { drill holes from this source publication. }\end{array}$ \\
\hline $\begin{array}{l}\text { Robinson, L.N. and Van Gosen, B.S., 1985, Maps and sections showing } \\
\text { geology and coal resources of the northeastern part of the Crow Indian } \\
\text { Reservation, Big Horn County, Montana: U.S. Geological Survey Mis- } \\
\text { cellaneous Field Studies Map 1796, scale 1:24,000, } 9 \text { maps. }\end{array}$ & $\begin{array}{l}\text { Contains numerous drill hole and measured section locations on } \\
\text { maps with annotated coal intercepts. The published database } \\
\text { contains } 6 \text { drill holes from this source publication. }\end{array}$ \\
\hline
\end{tabular}


Table 4. Federal and State publications and online sources with original drill hole logs in the Powder River Basin. The publication number is contained in the location table DAT_SOURCE field. The Comment column describes the drill hole number series and type of logs contained.-Continued

\begin{tabular}{|c|c|}
\hline Source Publication & Comments \\
\hline $\begin{array}{l}\text { Robinson, L.N. and Van Gosen, B.S., 1986, Maps showing the coal } \\
\text { geology of the Sarpy Creek area, Big Horn and Treasure Counties, } \\
\text { Montana: U.S. Geological Survey Miscellaneous Field Studies Map } \\
\text { 1859, scale 1:24,000. }\end{array}$ & $\begin{array}{l}\text { Coal picks and location maps for drill holes numbered } 1 \text { through } \\
\text { 49. The published database contains } 57 \text { drill holes from this } \\
\text { source publication. }\end{array}$ \\
\hline $\begin{array}{l}\text { U.S. Geological Survey and Montana Bureau of Mines and Geology, } \\
\text { 1973, Preliminary report of coal drill hole data and chemical analyses } \\
\text { of coal beds in Sheridan and Campbell Counties, Wyoming, and Big } \\
\text { Horn County, Montana: U.S. Geological Survey Open-File Report } \\
\text { 73-351, 51 p. }\end{array}$ & $\begin{array}{l}\text { Lithology logs and coal quality for holes numbered BME-721 } \\
\text { through BME-7228. The published database contains } 21 \text { drill } \\
\text { holes from this source publication. }\end{array}$ \\
\hline $\begin{array}{l}\text { U.S. Geological Survey and Montana Bureau of Mines and Geology, } \\
\text { 1974, Preliminary report of coal drill hole data and chemical analyses } \\
\text { of coal beds in Campbell County, Wyoming: U.S. Geological Survey } \\
\text { Open-File Report 74-97, } 241 \text { p. }\end{array}$ & $\begin{array}{l}\text { Lithology logs and geophysical logs for holes numbered US-731 } \\
\text { through US-7363. The published database contains } 21 \text { drill holes } \\
\text { from this source publication. }\end{array}$ \\
\hline $\begin{array}{l}\text { U.S. Geological Survey and Montana Bureau of Mines and Geology, } \\
\text { 1976, Preliminary report of coal drill-hole data and chemical analyses } \\
\text { of coal beds in Campbell, Converse, and Sheridan Counties, Wyoming; } \\
\text { and Big Horn, Richland, and Dawson Counties, Montana: U.S. Geolog- } \\
\text { ical Survey Open-File Report 76-450, } 382 \text { p. }\end{array}$ & $\begin{array}{l}\text { Lithology logs, geophysical logs and coal quality for holes } \\
\text { numbered US-751 through US-75124. The published database } \\
\text { contains } 35 \text { drill holes from this source publication. }\end{array}$ \\
\hline $\begin{array}{l}\text { U.S. Geological Survey and Montana Bureau of Mines and Geology, } \\
\text { 1977, Preliminary report of } 1977 \text { coal drilling in eastern Montana and } \\
\text { Northeastern Wyoming: Geophysical logs for Big Horn County, Mon- } \\
\text { tana: U.S. Geological Survey Open-File Report 77-721-B, } 126 \text { p. }\end{array}$ & $\begin{array}{l}\text { Geophysical logs for holes numbered US-7738 through US-7798. } \\
\text { The published database contains } 53 \text { drill holes from this source } \\
\text { publication. }\end{array}$ \\
\hline $\begin{array}{l}\text { U.S. Geological Survey and Montana Bureau of Mines and Geology, } \\
\text { 1978, Preliminary report of } 1977 \text { coal drilling in eastern Montana and } \\
\text { northeastern Wyoming: Geophysical logs for Big Horn, Fallon, and } \\
\text { Powder River Counties, Montana: U.S. Geological Survey Open-File } \\
\text { Report 77-721-A, } 77 \text { p. }\end{array}$ & $\begin{array}{l}\text { Geophysical logs for holes numbered US- } 771 \text { through US- }-7737 \text {. } \\
\text { The published database contains } 26 \text { drill holes from this source } \\
\text { publication. }\end{array}$ \\
\hline $\begin{array}{l}\text { U.S. Geological Survey and Montana Bureau of Mines and Geology, } \\
\text { 1978, Preliminary report of } 1977 \text { coal drilling in eastern Montana } \\
\text { and Northeastern Wyoming: Geophysical logs for Powder River and } \\
\text { Dawson Counties, Montana: U.S. Geological Survey Open-File Report } \\
\text { 77-721-C, } 79 \text { p. }\end{array}$ & $\begin{array}{l}\text { Geophysical logs for holes numbered US-7799 through US- } \\
77148 \text {. The published database contains } 41 \text { drill holes from this } \\
\text { source publication. }\end{array}$ \\
\hline $\begin{array}{l}\text { U.S. Geological Survey and Montana Bureau of Mines and Geology, } \\
\text { 1978, Preliminary report of } 1977 \text { coal drilling in eastern Montana and } \\
\text { Northeastern Wyoming: Geophysical logs for Dawson, Garfield, Mc- } \\
\text { Cone, and Prairie Counties, Montana: U.S. Geological Survey Open- } \\
\text { File Report 77-721-D, } 101 \text { p. }\end{array}$ & $\begin{array}{l}\text { Geophysical logs for holes numbered US- } 77149 \text { through } \\
\text { US- } 77199 . \text { The published database contains } 6 \text { drill holes from } \\
\text { this source publication. }\end{array}$ \\
\hline
\end{tabular}


Table 4. Federal and State publications and online sources with original drill hole logs in the Powder River Basin. The publication number is contained in the location table DAT_SOURCE field. The Comment column describes the drill hole number series and type of logs contained.-Continued

\begin{tabular}{|c|c|}
\hline Source Publication & Comments \\
\hline $\begin{array}{l}\text { U.S. Geological Survey and Montana Bureau of Mines and Geology, } \\
\text { 1978, Preliminary report of } 1977 \text { coal drilling in eastern Montana and } \\
\text { Northeastern Wyoming: Geophysical logs for Campbell and Con- } \\
\text { verse Counties, Wyoming: U.S. Geological Survey Open-File Report } \\
\text { 77-721-E, } 202 \text { p. }\end{array}$ & $\begin{array}{l}\text { Geophysical logs for holes numbered US- } 77200 \text { through US- } \\
77290 \text {. The published database contains } 72 \text { drill holes from this } \\
\text { source publication. }\end{array}$ \\
\hline $\begin{array}{l}\text { U.S. Geological Survey and Montana Bureau of Mines and Geology, } \\
\text { 1978, Preliminary report of } 1977 \text { coal drilling in eastern Montana } \\
\text { and northeastern Wyoming: Geophysical logs for Dawson, McCone, } \\
\text { Richland, and Rosebud Counties, Montana: U.S. Geological Survey } \\
\text { Open-File Report 77-721-F, } 74 \text { p. }\end{array}$ & $\begin{array}{l}\text { Geophysical logs for holes numbered US- }-77291 \text { through US- } \\
77317 \text {. The published database contains } 2 \text { drill holes from this } \\
\text { source publication. }\end{array}$ \\
\hline $\begin{array}{l}\text { U.S. Geological Survey and the Montana Bureau of Mines and Geol- } \\
\text { ogy, 1980, Coal drilling during } 1978 \text { in Big Horn, Daniels, Dawson, } \\
\text { Musselshell, Richland, Roosevelt, Rosebud, Valley, and Yellowstone } \\
\text { Counties, Montana: U.S. Geological Survey Open-File Report 80-267, } \\
273 \text { p. }\end{array}$ & $\begin{array}{l}\text { Lithology logs and geophysical logs for holes numbered US-781 } \\
\text { through US-78196. The published database contains } 12 \text { drill holes } \\
\text { from this source publication. }\end{array}$ \\
\hline $\begin{array}{l}\text { U.S. Geological Survey and the Montana Bureau of Mines and Geol- } \\
\text { ogy, 1981, Coal drilling during } 1980 \text { in Big Horn, Dawson, McCone, } \\
\text { Powder River, Prairie, Richland, Rosebud, and Treasure Counties, } \\
\text { Montana: U.S. Geological Survey Open-File Report 82-26, } 258 \text { p. }\end{array}$ & $\begin{array}{l}\text { Geophysical logs for holes numbered US- } 80001 \text { through US- } \\
80128 \text {. The published database contains } 58 \text { drill holes from this } \\
\text { source publication. }\end{array}$ \\
\hline $\begin{array}{l}\text { Wyoming Oil and Gas Conservation Commission } \\
\text { http://wogcc.state.wy.us/. }\end{array}$ & $\begin{array}{l}\text { Web site contains scanned logs of all Oil and Gas and Coalbed } \\
\text { Methane wells in Wyoming along with location information for all } \\
\text { wells. The published database contains } 16,716 \text { drill holes down- } \\
\text { loaded from this source. }\end{array}$ \\
\hline
\end{tabular}


Table 5. List of the contents of the stratigraphy table PRIME_LITH and LITH_MOD fields and the number of occurrences of each combination.

\begin{tabular}{|c|c|c|}
\hline Number of occurrences & Primary lithology & Lithology modifier \\
\hline 2 & Chert & \\
\hline 10,972 & Claystone & \\
\hline 12 & Claystone & Bentonite \\
\hline 12 & Claystone & Calcareous \\
\hline 116 & Claystone & Carb/coaly \\
\hline 53 & Claystone & Carb/silty \\
\hline 2,544 & Claystone & Carbonaceous \\
\hline 189 & Claystone & Coaly \\
\hline 50 & Claystone & Root \\
\hline 1,442 & Claystone & Sandy \\
\hline 15 & Claystone & Shaley \\
\hline 475 & Claystone & Silty \\
\hline 30 & Claystone & Silty/carb \\
\hline 6 & Claystone & Silty/sandy \\
\hline 122 & Clinker & \\
\hline 130,478 & Coal & \\
\hline 15 & Coal & Boney \\
\hline 792 & Coal & Cbm perf \\
\hline 3 & Coal & Clayey \\
\hline 19,890 & Coal & High ash \\
\hline 187 & Coal & Mod ash \\
\hline 607 & Coal & Shaley \\
\hline 106 & Conglomerate & \\
\hline 153 & Interbedded & \\
\hline 2 & Ironstone & \\
\hline 253 & Limestone & \\
\hline 16 & Limestone & Shaley \\
\hline 4,229 & Mudstone & \\
\hline 6 & Mudstone & Bentonite \\
\hline 172 & Mudstone & Carbonaceous \\
\hline 38 & Mudstone & Coaly \\
\hline 157 & Mudstone & Sandy \\
\hline 45 & Mudstone & Silty \\
\hline 2 & Mudstone & Silty/carb \\
\hline 6,469 & No $\log$ & \\
\hline 25,319 & Not recorded & \\
\hline
\end{tabular}


Table 5. List of the contents of the stratigraphy table PRIME_LITH and LITH_MOD fields and the number of occurrences of each combination.-Continued.

\begin{tabular}{|c|c|c|}
\hline Number of occurrences & Primary lithology & Lithology modifier \\
\hline 2 & Pyrite & \\
\hline 118,649 & Rock & \\
\hline 6 & Sand & \\
\hline 13,126 & Sandstone & \\
\hline 340 & Sandstone & Calcareous \\
\hline 272 & Sandstone & Carbonaceous \\
\hline 239 & Sandstone & Clayey \\
\hline 6 & Sandstone & Coaly \\
\hline 2 & Sandstone & Conglomeritic \\
\hline 2 & Sandstone & Cross bedded \\
\hline 2 & Sandstone & Fossiliferous \\
\hline 12 & Sandstone & Muddy \\
\hline 72 & Sandstone & Shaley \\
\hline 728 & Sandstone & Silty \\
\hline 3,614 & Shale & \\
\hline 7 & Shale & Bentonite \\
\hline 4 & Shale & Calcareous \\
\hline 92 & Shale & Carb/coaley \\
\hline 4 & Shale & Carb/silty \\
\hline 2,837 & Shale & Carbonaceous \\
\hline 87 & Shale & Coaly \\
\hline 318 & Shale & Sandy \\
\hline 5,276 & Siltstone & \\
\hline 6 & Siltstone & Burrowed \\
\hline 48 & Siltstone & Calcareous \\
\hline 544 & Siltstone & Carbonaceous \\
\hline 200 & Siltstone & Clayey \\
\hline 15 & Siltstone & Muddy \\
\hline 6 & Siltstone & Root \\
\hline 406 & Siltstone & Sandy \\
\hline 176 & Siltstone & Shaley \\
\hline 121 & Soil & \\
\hline 3 & Surface gravel & \\
\hline 282 & Surface material & \\
\hline
\end{tabular}




\section{References Cited}

Culberston, W.C., Kent, B.H., and Maple, W.J., 1979, Preliminary diagrams showing correlation of coal beds in the Fort Union and Wasatch Formations across the Northern Powder River Basin, north-eastern Wyoming and southeastern Montana: U.S. Geological Survey Open-File Report 79-1201, 11 p., 2 diagrams, no scale.

Culbertson, W.C., and Saperstone, H.I., 1987, Structure, coal thickness, and overburden thickness of the Knobloch coal resource unit, Birney area, Big Horn, Rosebud, and Powder River Counties, Montana: U.S. Geological Survey Coal Investigations Map C-112, scale 1:100,000.

Esri, Inc., 2000, ArcGIS: Redlands, Calif, Esri. Available at http://www.esri.com/software/arcgis/index.html.

Esri, Inc., 2008a, ArcPublisher: Redlands, Calif., Esri. Available at http://www.esri.com/software/arcgis/extensions/ publisher/index.html.

Esri, Inc. (ESRI), 2008b, ArcReader: Redlands, Calif. Esri. Available at http://www.esri.com/software/arcgis/arcreader/ download.html.

Esri, Inc., 2010, ArcGIS online services-Ready-to-use content on demand: Redlands, Calif., Esri. Available at http:// www.esri.com/software/arcgis/arcgisonline/index.html.

Flores, R.M., Ochs, A.M., Bader, L.R., Johnson, R.C., and Vogler, P.D., 1999, Framework geology of the Fort Union coal in the Powder River Basin, Chap. PF in 1999 Resource assessment of selected Tertiary coal beds and zones in the Northern Rocky Mountains and Great Plains Region: U.S. Geological Survey Professional Paper 1625-A, 2 CD-ROMs.

Goolsby, Finley, and Associates, 2001, Drill hole database: Casper, Wyo., Goolsby. Finley, and Associates, LLC.

GRG Corporation, 1998, StratiFact software version 4.57: Wheat Ridge, Colo., GRG Corporation.

Haacke, J.E., Scott, D.C. Osmonson L.M., Luppens, J.A., Pierce, P.E., and Gunderson, J.A., 2013, Coal geology and assessment of resources and reserves in the Montana Powder River Basin: U.S. Geological Survey Open-File Report 2012-1113.

Hardie, J.K., 1991, Cross sections showing coal stratigraphy of the southwestern Powder River Basin, Wyoming: U.S. Geological Survey Miscellaneous Investigations Series Map I-1959-C, scale 1:500,000.
Kent, B.H., Berlage, L.J., and Boucher, E.M., 1980, Stratigraphic framework of coal beds underlying the western part of the Recluse $1 \times 1 / 2$-degree quadrangle, Campbell County, Wyoming: U.S. Geological Survey Coal Investigations Map C-81C, 2 pl., scale: 1:100,000.

Law, B.E., Barnum, B.E., and Wollenzien, T.P., 1979, Coal bed correlations in the Tongue River Member of the Fort Union Formation, Monarch, Wyoming, and Decker, Montana, areas: U.S. Geological Survey Miscellaneous Investigations Series Map I-1128, scale 1:24,000.

Luppens, J.A., Scott, D.C., Haacke, J.E., Osmonson, L.M., Rohrbacher, T.J., and Ellis, M.S., 2008, Assessment of Coal Geology, Resources, and Reserves in the Gillette coal field, Powder River Basin, Wyoming: U.S. Geological Survey Open-File Report 2008-1202, 127 p.

McLellan, M.W., 1991, Cross section showing the reconstructed stratigraphic framework of Paleocene rocks and coal beds in the central Powder River Basin from Decker to Bear Skull Mountain, Montana: U.S. Geological Survey Miscellaneous Investigations Series Map I-1959-E, 2 cross sections, no scale.

McLellan, M.W., Biewick, L.R.H., Molnia, C.L., and Pierce, F.W., 1990, Cross sections showing the reconstructed stratigraphic framework of Paleocene rocks and coal beds in the northern and central Powder River Basin, Montana and Wyoming: U.S. Geological Survey Miscellaneous Investigations Series Map I-1959-A, scale 1:500,000.

MJ Systems, 2009, MJ Systems well log catalogue: Denver, Colo., MJ Systems. Accessed on April, 2008, at http://www.mjlogs.com/.

Molnia, C.L. and Pierce, F.W., 1992, Cross sections showing coal stratigraphy of the central Powder River basin, Wyoming and Montana, : U.S. Geological Survey Miscellaneous Investigations Series Map I-1959-D, scale 1:500,000.

Montana Board of Oil and Gas, 2006, Report and Data, Billings, Mont.: Montana Board of Oil and Gas. Accessed on May, 2006 at http://bogc.dnrc.mt.gov/onlinedata.asp

Olive, W.W., 1957, The Spotted Horse Coal Field, Sheridan and Campbell Counties, Wyoming: U.S. Geological Survey Bulletin 1050, 83 p.

Osmonson L.M., Scott, D.C., Haacke, J.E., Luppens, J.A., and Pierce, P.E., 2011, Assessment of coal geology, resources, and reserves in the southwestern Powder River Basin, Wyoming: U.S. Geological Survey Open-File Report 2011-1134, 135 p. 
Pierce, F.W., Johnson, E.A., Molnia, C.L., and Sigleo, W.R., 1990, Cross sections showing coal stratigraphy of the southeastern Powder River Basin, Wyoming: U.S. Geological Survey Miscellaneous Investigations Series Map I-1959-B, scale 1:500,000.

Scott, D.C., Haacke, J.E., Osmonson L.M., Luppens, J.A., Pierce, P.E., and Rohrbacher, T.J., 2010, Assessment of coal geology, resources, and reserves in the northern Wyoming Powder River Basin, Wyoming: U.S. Geological Survey Open-File Report 2010-1294, 136 p.

U.S. Army Corps of Engineers, 2004, Corpscon version 6.0: U.S. Army Corps of Engineers, National Datums and Subsidence Program. Available at http://www.agc.army.mil/ corpscon/.

Publishing support provided by:

Denver Publishing Service Center

For more information concerning this publication, contact: Center Director, USGS Central Energy Resources Science Center Box 25046, Mail Stop 939

Denver, CO 80225

(303) 236-1647

Or visit the Central Energy Resources Science Center Web site at: http://energy.usgs.gov/ 


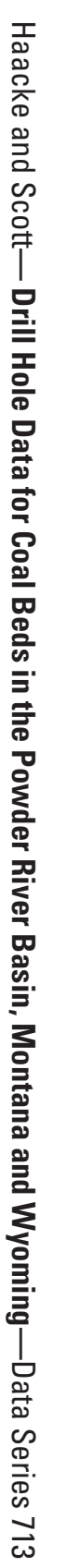

